\title{
PENGARUH MODEL TEAM ASSISTED INDIVIDUALIZATION (TAI) TERHADAP HASIL BELAJAR BIOLOGI SISWA KELAS X SMA NEGERI 8 LUBUKLINGGAU
}

\author{
Sepriyaningsih", Dian Samitra, Meti Yunita
}

\author{
Pendidikan Biologi, STKIP PGRI LUBUKLINGGAU \\ ${ }^{*}$ Corresponding author: sepriyaningsih26@gmail.com
}

DOI: $10.31932 / j p b i o . v 4 i 1.368$

\begin{abstract}
ABSTRAK
Berdasarkan hasil wawancara yang dilakukan penulis dengan salah satu guru mata pelajaran biologi kelas X SMA Negeri 8 Lubuklinggau diperoleh data bahwa kemampuan siswa dalam memahami materi biologi masih rendah. Hal itu disebabkan kurang aktifnya siswa dalam pembelajaran. Untuk mengatasi masalah tersebut diperlukan model-model pembelajaran yang dapat mengaktifkan siswa untuk mempelajari pelajaran biologi.Tujuan penelitian ini adalah untuk mengetahui pengaruh model pembelajaran Team Assisted Individualization terhadap hasil belajar biologi siswa kelas X SMA Negeri 8 Lubuklinggau tahun ajaran 2016/2017. Metode penelitian yang digunakan dalam penelitian ini adalah metode eksperimen dengan desain Control group pre-test dan post-test. Berdasarkan hasil analisis uji-t pada taraf signifikan $=0,05$, diperoleh $t_{\text {hitung }}(8,43)>t_{\text {tabel }}(1,684)$. Dapat disimpulkan ada pengaruh yang signifikan model pembelajaran Team Assisted Individualization terhadap hasil belajar siswa kelas X biologi SMA Negeri 8 Lubuklinggau tahun ajaran 2016/2017.
\end{abstract}

Kata kunci: team assisted individualization, hasil belajar, biologi.

\section{ABSTRACT}

Based on the results of interviews conducted by the writer with one of the biology class teachers of class $X$ Lubuklinggau 8 SMA obtained data that students' ability to understand biological material is still low. This is due to the lack of active students in learning. To overcome this problem, learning models are needed that can enable students to learn biology. The purpose of this study was to determine the effect of Team Assisted Individualization learning models on biology learning outcomes of class $X$ students of SMA 8 Lubuklinggau in the academic year 2016/2017. The research method used in this study is an experimental method with a control group design pre-test and post-test. Based on the results of the t-test analysis at a significant level $=0.05$, $t$ count (8.43)> $t$ table (1.684) was obtained. It can be concluded that there is a significant effect of the Team Assisted Individualization learning model on the learning outcomes of biology class $X$ students of SMA 8 Lubuklinggau in the academic year 2016/2017.

Keywords: team assisted individualization, learning outcomes, biology.

\section{PENDAHULUAN}

Menurut Trianto (2007:1), pendidikan yang baik tidak hanya mempersiapkan para siswanya untuk suatu profesi atau jabatan, tetapi untuk menyelesaikan masalah-masalah yang dihadapi dalam kehidupan sehari-hari. Proses pendidikan yang dilakukan dengan baik, tentunya akan menghasilkan manusia yang berkualitas sehingga mampu dan proaktif menjawab tantangan zaman yang berubah. Sebagian besar penyelenggaraan pendidikan saat ini masih berpusat pada guru. Hal ini memberikan dampak yang kurang baik terhadap anak.

Citation: Sepriyaningsih, Samitra, D., \& Yunita, M. (2019). Pengaruh model team assisted individualization (TAI) terhadap hasil belajar biologi siswa kelas X SMA Negeri 8 Lubuklinggau. JPBIO (Jurnal Pendidikan Biologi), 4(1): 29-34. DOI: 
Proses pembelajaran di dalam kelas diarahkan kepada kemampuan anak untuk menghafal informasi, otak anak dipaksa untuk mengingat dan menimbun berbagai informasi tanpa dituntut untuk memahami informasi yang diingatnya itu untuk menghubungkannya dengan kehidupan sehari-hari (Sanjaya, 2006:1). Oleh sebab itu, untuk mengembangkan kemampuan berpikir siswa, guru harus melibatkan siswa dalam kegiatan pembelajaran. Salah satu cara untuk mengembangkan kemampan berpikir siswa yaitu dengan mengembangkan model yang tepat dalam kegiatan pembelajaran.

Disekolah sering ditemui kendala dan hambatan sehingga hasil belajar siswa dalam mata pelajaran biologi masih rendah. Berdasarkan hasil wawancara yang dilakukan penulis dengan salah satu guru mata pelajaran biologi kelas X SMA Negeri 8 Lubuklinggau pada tanggal 19 Agustus 2016 dan 29 Maret 2017 diperoleh data bahwa kemampuan siswa dalam memahami materi biologi masih rendah. Hal ini terlihat dari rata-rata nilai ulangan harian siswa pada mata pelajaran biologi yang dicapai masih rendah di bawah Kriteria Ketuntasan Minimal (KKM) yang ditetapkan oleh sekolah untuk mata pelajaran biologi kelas $X$ adalah 72 . Hasil penelitian Reflianto et al. (2019) menunjukan nilai hasil belajar kognitif siswa yang belum optimal yakni masih 55\% siswa yang belum tuntas. Lebih lanjut, penelitian Mulyono et al. (2017) juga menunjukan hasil belajar kognitif siswa biologi masih di bawah nilai ketuntasan minimal yakni baru mencapai $65 \%$ dengan kategori cukup.

Rendahnya hasil belajar dikarenakan siswa kurang aktif dalam pembelajaran. Untuk mengatasi masalah tersebut diperlukan model-model pembelajaran yang dapat mengaktifkan siswa untuk mempelajari pelajaran biologi dan meningkatkan hasil belajar. Model yang digunakan harus sesuai dengan tujuan pembelajaran serta jenis materi yang diajarkan. Salah satu model pembelajaran yang dapat digunakan adalah model pembelajaran Team Assisted Individualization (TAI). Menurut Huda (2012:125), langkah-langkah dalam model Team Assisted Individualization yaitu mengelompokkan siswa berdasarkan kemampuannya yang beragam, masing-masing kelompok terdiri dari 4 siswa yang ditugaskan untuk menyelesaikan materi pembelajaran atau Pekerjaan Rumah (PR) tertentu untuk dikerjakan bersama-sama.

Poin-poin tugas dibagikan secara berurutan kepada setiap anggota, selama menjalani tes individu ini, guru harus memperhatikan setiap siswa, skor tidak hanya dinilai oleh sejauh mana siswa mampu menjalani tes itu, tetapi sejauh mana siswa mampu bekerja secara mandiri setiap minggu, guru menjumlahkan ada berapa banyak soal yang bisa dijawab oleh masing-masing kelompok yang mampu menjawab soal-soal yang benar lebih banyak dan mampu menyelesaikan PR dengan baik. Guru memberikan poin tambahan kepada individuindividu siswa yang mampu memperoleh nilai rata-rata pada ujian final. Berdasarkan penelitian Erdriani (2014) menyatakan model TAl lebih ditekankan pada pengalaman belajar, bekerjasama, dan evaluasi setiap akhir pembelajaran sehingga berpengaruh terhadap kemampuan pemecahan masalah peserta didik, sedangkan pada pembelajaran dengan model konvensional peserta didik hanya dituntut menyelesaikan masalah secara individual melalui pemberian latihan dan pekerjaan rumah.

Menurut Tilyani (2007:8), dalam model pembelajaran TAI ini diharapkan dapat meningkatkan cara berpikir, kreatifitas, dan menumbuhkan rasa sosial yang tinggi para siswa karena model tersebut menggunakan pembelajaran kelompok. hasil belajar adalah suatu yang diperoleh individu atau kelompok setelah melakukan kegiatan belajar. Hasil belajar yang dimaksud dalam penelitian ini adalah hasil yang diperoleh siswa setelah melakukan kegiatan belajar biologi dengan menggunakan Model Pembelajaran Team Assisted Individualization Untuk meningkatkan hasil belajar biologi siswa dengan cara berpikir kreatif maka perlu dilakukan penelitian dengan menerapkan model TAI ini. Oleh sebab itu, peneliti mengadakan penelitian yang berjudul "Pengaruh Model Team Assisted Individualization terhadap Hasil Belajar Biologi Siswa Kelas X SMA Negeri 8 Lubuklinggau."

\section{METODE PENELITIAN}

\section{Rancangan Penelitian}

Rancangan penelitian merujuk pada kerangka konseptual yang akan dilakukan dalam penelitian, karena penelitian ini dilaksanakan untuk memperoleh bukti-bukti yang paling 
meyakinkan tentang pengaruh satu variabel terhadap variabel yang lain. Jenis penelitiannya adalah penelitian kuantitatif penelitian ilmiah yang sistematis terhadap bagian-bagian dan fenomena serta hubungan-hubungannya murni berbentuk desain (Control Group Pretestpostest Design).

\section{Populasi dan Sampel Penelitian}

Menurut Arikunto (2010:173), populasi adalah keseluruhan subjek penelitian. Apabila seseorang ingin meneliti semua elemen yang ada dalam wilayah penelitian, maka penelitiannya merupakan penelitian populasi. Populasi dalam penelitian ini adalah siswa kelas X SMA Negeri 8 Lubuklinggau dengan jumlah 126 siswa. Penelitian ini pengambilan sampel diambil dengan menggunakan Simple Random Sampling dikatakan secara acak tanpa memperhatikan strata yang ada dalam populasi. Setelah melakukan pengundian, didapat kelas yang akan dijadikan sampel penelitian yaitu kelas X.1 sebagai kelas eksperimen dan kelas X.5 sebagai kelas kontrol. Pada kelas eksperimen akan diberikan perlakuan pembelajaran dengan menggunakan model Team Assisted Individualization dengan jumlah siswa 26 orang terdiri 11 laki-laki dan 15 perempuan, sedangkan pada kelas kontrol akan diberikan perlakuan pembelajaran konvensional dengan jumlah siswa 24 terdiri dari 11 lakilaki dan 13 perempuan.

\section{Instrumen Penelitian}

Arikunto (2010:193) menyatakan bahwa Tes adalah Serentetan pertanyaan atau latihan yang digunakan untuk mengukur keterampilan, pengetahuan inteligensi, kemampuan atau bakat yang dimiliki oleh individu atau kelompok. Tes yang digunakan dalam penelitian ini berbentuk pilihan ganda sebanyak 20 soal. Sebelum tes dilakukan terlebih dahulu soal instrumen di uji coba. Uji coba tes dilakukan untuk mengetahui kualitas soal yang akan digunakan sebagai alat pengumpul data. Tes dikatakan baik sebagai alat pengukur, harus memenuhi persyaratan tes, yaitu untuk mengetahui apakah validitas reabel untuk digunakan dalam penelitian ini. Dengan demikian soal tes yang akan digunakan dalam penelitian ini sudah diketahui validitas, reliabilitas, tingkat kesukaran dan daya pembeda. Tes yang dilakukan ada dua tahap yaitu tes awal (pre-test) dan tes akhir (post-test).

\section{Prosedur Penelitian}

Penelitian ini menggunakan 2 kelas yakni kelas eksperimen dan kelas kontrol. Sebelum memberikan perlakuan pembelajaran, terlebih dahulu diadakan pre-test pada kelas eksperimen dan kelas kontrol. Dilakukan teknik analisis data untuk mengetahui kemampuan awal sampel sebelum diberikan perlakuan pembelajaran. Setelah mengadakan pre-test kemudian pada kelas eksperimen diterapkan pembelajaran biologi dengan menggunakan model Team Assisted Individualization sedangkan kelas kontrol diterapkan dengan menggunakan pembelajaran konvensional. Setelah proses belajar mengajar selesai, dilakukan post-test pada kelas eksperimen dan kontrol dengan menggunakan soal evaluasi yang sama. Post- test dilakukan untuk mengetahui kemampuan akhir sampel setelah diberikan perlakuan pembelajaran. Setelah semua data terkumpul kemudian data dianalisis dan menarik kesimpulan dari semua data yang ada.

\section{Teknik Analisis Data}

Analisis data yang dilakukan dalam penelitian ini terhadap hasil belajar adalah uji skor rata-rata dan simpangan baku, uji normalitas, uji homogenitas serta uji hipotesis. Pengujian hipotesis dalam penelitian ini menggunakan rumus kesamaan dua rata-rata. Uji kesamaan rata-rata digunakan untuk mengetahui ada atau tidak adanya perbedaan (kesamaan) hasil belajar setelah diberi perlakuan antara kelas kontrol dan kelas eksperimen.

\section{HASIL PENELITIAN}

\section{Kemampuan Awal Siswa (Pre-test)}

Dari hasil analisis data yang diperoleh dari tes awal dapat dilakukan rekapitulasi nilai 
rata-rata $(x)$ dan simpangan baku $(s)$ yang terdapat pada Tabel 1 berikut ini.

Tabel 1. Nilai Rata-Rata dan Simpangan Baku Data Pre-Test

\begin{tabular}{ccc}
\hline Kelas & Rata-rata $(\boldsymbol{x})$ & Simpangan Baku (s) \\
\hline Eksperimen & 52,88 & 7,77 \\
\hline Kontrol & 52,71 & 7,80 \\
\hline
\end{tabular}

Uji normalitas ini bertujuan untuk mengetahui apakah data hasil pre- test siswa dikedua kelas berdistribusi normal atau tidak. Jika $X^{2}$ Hitung $<X^{2}$ Tabel, maka data berdistribusi normal. Sebaliknya, jika $X^{2}{ }_{\text {Hitung }} \geq X^{2}{ }_{\text {Tabel, }}$ maka data tidak berdistribusi normal.

Tabel 2. Hasil Uji Normalitas Data Pre-Test

\begin{tabular}{ccc}
\hline Kelas & $\boldsymbol{X}^{2}$ Hitung & $\boldsymbol{X}^{2}{ }_{\text {Tabel }}$ \\
\hline Eksperimen & 1,14 & 11,07 \\
\hline Kontrol & 1,25 & 11,07 \\
\hline Keterangan & Data Berdistribusi Normal & Data Berdistribusi Normal \\
\hline
\end{tabular}

Uji homogenitas dilakukan dengan membandingan antara $F_{\text {hitung }}$ dan $F_{\text {tabel. }} F_{\text {hitung }}$ diperoleh dari hasil bagi antara varians terbesar dengan varians terkecil, sedangkan $F_{\text {tabel }}$ diperoleh berdasarkan Tabel harga distribusi $F$ dengan menentukan nilai pembilang dan penyebut serta $\alpha=5 \%$. Berdasarkan perhitungan didapatkan nilai $F_{\text {hitung }}=0,99$ dan $F_{\text {Tabel }}=$ 2,00 . Artinya $F_{\text {hitung }}<F_{\text {tabel, }}$ maka kedua kelas homogen.

Karena kedua kelas telah berdistribusi normal dan homogen, maka uji kesamaan dua rata-rata dapat menggunakan uji t. Hipotesis statistik yang diuji dalam perhitungan uji-t untuk pre-test adalah:
$\mathrm{H}_{0}: \mu_{1}=\mu_{2}$
: Hipotesis nol atau pembanding, rata-rata nilai kelas eksperimen
$\mathrm{H}_{\mathrm{a}}: \mu_{1} \neq \mu_{2}$ sama dengan rata-rata nilai kelas kontrol.
: Hipotesis alternatif atau kerja, rata-rata nilai kelas eksperimen tidak sama dengan rata-rata nilai kelas kontrol.

Berdasarkan hasil perhitungan didapatkan nilai $t_{\text {hitung }}=0,07$ dan $t_{\text {tabel }}=2,021$. Jadi $t_{\text {hitung }}<$ $\mathrm{t}_{\text {tabel, }}$ maka $\mathrm{H}_{0}$ diterima. Artinya kedua rata-rata nilai pre-test kelas eksperimen dan kontrol adalah sama.

\section{Kemampuan Akhir Siswa (Post-test)}

Kemampuan akhir siswa diukur dengan memberikan post-test (tes akhir) dengan soal yang sama diberikan pada tes awal setelah siswa mengikuti proses belajar mengajar, tes ini diberikan untuk mengetahui sejauh mana hasil belajar siswa setelah mengikuti pembelajaran dengan materi Ekosistem yang diterapkan baik pada kelas eksperimen maupun kelas kontrol. Dari hasil analisis data yang diperoleh dari tes akhir dapat dilakukan rekapitulasi nilai rata-rata $(x)$ dan simpangan baku $(s)$ dapat dilihat pada Tabel 3.

Tabel 3. Nilai Rata-Rata dan Simpangan Baku Data Post-Test

\begin{tabular}{ccc}
\hline Kelas & Rata-Rata $(\boldsymbol{x})$ & Simpangan Baku $(\boldsymbol{s})$ \\
\hline Eksperimen & 77,69 & 15,18 \\
\hline Kontrol & 69,17 & 10,90 \\
\hline
\end{tabular}

Tabel 4. Hasil Uji Normalitas Data Post-Test

\begin{tabular}{ccc}
\hline Kelas & $\boldsymbol{X}^{2}$ Hitung & $\boldsymbol{X}_{\text {tabel }}$ \\
\hline Eksperimen & 3,69 & 11,07 \\
\hline Kontrol & 3,83 & 12,59 \\
\hline Keterangan & Data Berdistribusi Normal & Data berdistribusi Normal \\
\hline
\end{tabular}


Perhitungan uji homogenitas menyatakan bahwa data post-test kedua kelas yang dijadikan sampel memiliki varians-varians yang homogen. Dengan $F_{\text {hitung }}=1,71$ dan $F_{\text {tabel }}=$ 2,00 artinya $F_{\text {hitung }}<F_{\text {tabel, }}$ maka kedua kelas homogen.

Hasil perhitungan sebelumnya telah menunjukkan bahwa kedua kelas berdistribusi normal dan memiliki varians yang homogen, maka pengujian hipotesis dapat menggunakan uji t. Hipotesis statistiknya adalah sebagai berikut:

$$
\begin{array}{ll}
\mathrm{H}_{0}: \mu_{1} \leq \mu_{2} & \begin{array}{l}
\text { : Hipotesis nol atau pembanding, rata-rata nilai kelas eksperimen } \\
\text { kurang dari atau sama dengan rata-rata nilai kelas kontrol. }
\end{array} \\
& \begin{array}{l}
\text { : Hipotesis alternatif atau kerja, rata-rata nilai kelas eksperimen } \\
\mathrm{H}_{\mathrm{a}}: \mu_{1}>\mu_{2}
\end{array}
\end{array}
$$

$t_{\text {hitung }}=8,43$ sedangkan $t_{\text {tabel }}=1,68$, jadi $t_{\text {hitung }}>t_{\text {tabel }}$, maka $\mathrm{H}_{0}$ ditolak dan $\mathrm{H}_{\mathrm{a}}$ diterima. Artinya rata-rata nilai eksperimen lebih besar daripada rata-rata nilai kelas kontrol.

\section{PEMBAHASAN}

Setelah melakukan pre-test, peneliti memberi perlakuan pada pertemuan pertama, pada kelas eksperimen menggunakan model Team Asssited Individualization (TAI) dan kelas kontrol menggunakan model konvensional. Pelaksanaan pembelajaran pada kelas eksperimen dengan model TAI mengalami sedikit hambatan. Pembelajaran yang baru bagi siswa, sehingga siswa membutuhkan waktu untuk penyesuaian. Hal ini sesuai dengan pendapat Slameto (2010:63) bahwa penerapan model yang tidak jelas, akan menimbulkan kesulitan bagi siswa dalam memahami konsep materi sehingga dapatlah diprediksi tujuan pembelajaran yang telah ditetapkan sulit tercapai secara optimal. Akibat yang dapat ditimbulkan adalah haasil belajar siswa menjadi kurang maksimal.

Kegiatan treatment pada pertemuan kedua di kelas eksperimen dalam materi komponen ekosistem dan interaksi makhluk hidup dengan lingkungannya dengan menggunakan model Team Assisted Individualization, terdapat beberapa hambatan yang dihadapi, yaitu beberapa siswa dalam tiap kelompok yang kurang antusias dalam mengikuti kegiatan diskusi kelompok untuk menyelesaikan tugas yang diberikan, karean 4 kelompok belajar sudah dapat bekerja sama dengan baik mengerjakan tugas yang diberikan dan 2 kelompok belajar masih kesulitan bekerja sama mengerjakan tugas sehingga guru harus memberikan pendekatan kepada siswa dalam kelompok belajar tersebut untuk meningkatkan motivasi dan kerjasama mereka dalam mengerjakan tugas yang diberikan. Selanjutnya pada pertemuan ketiga, proses pembelajaran kelas eksperimen berlangsung dengan baik. Karena 6 kelompok belajar sudah dapat bekerja sama dengan baik mengerjakan tugas yang diberikan. Berdasarkan penelitisn Erdriani (2014) menyatakan bahwa hasil belajar siswa dengan menggunakan model pembelajaran kooperatif tipe TAI lebih baik dibandingkan dengan hasil belajar siswa dengan model pembelajaran konvensional. Hal ini disebabkan karena pada pembelajaran dengan model TAI lebih ditekankan pada pengalaman belajar, bekerjasama, dan evaluasi setiap akhir pembelajaran sehingga berpengaruh terhadap kemampuan pemecahan masalah peserta didik, sedangkan pada pembelajaran dengan model konvensional peserta didik hanya dituntut menyelesaikan masalah secara individual melalui pemberian latihan dan pekerjaan rumah. Selain itu, menurut Isa, dkk (2017) bahwa pembelajaran dengan model TAI memberi perbedan yang signifikan dalam pemahaman konsepdan keterampilan berpikir kritis siswa dibandingkan dengan pembelajaran model konvensional.

Setelah diberikan perlakuan pada kelas eksperimen dan kontrol, kemudian peneliti melakukan tes akhir (post-test) pada kelas eksperimen dan kontrol. Bila diuraikan hasil tes materi ekosistem siswa setelah diberikan dengan model Team Assisted Individualization (posttest) di kelas eksperimen lebih meningkat dari hasil tes dengan pembelajaran konvensional pada kelas kontrol dengan nilai rata-rata tes akhir (post-test) yang diperoleh siswa kelas eksperimen adalah 77,69 lebih besar daripada nilai rata-rata hasil tes akhir (post-test) diperoleh siswa kelas kontrol adalah 69,17. Hal ini menunjukkan bahwa hasil tes kelas eksperimen lebih besar dari hasil tes kelas kontrol dengan selisih peningkatan nilai rata-rata 
sebesar 8,52. Hal ini sesuai dengan hasil penelitian Halih (2016) bahwa siswa yang diberi model pembelajaran TAI memiliki nilai rata-rata lebih tinggi daripada model pembelajaran konvensional.

\section{SIMPULAN}

Berdasarkan hasil penelitian diperoleh hasil analisis data menggunakan uji-t menunjukkan $t_{\text {hitung }}$ sebesar 8,43 dan $t_{\text {tabel }}$ sebesar 1,68 , artinya $\mathrm{H}_{\circ}$ ditolak dan $\mathrm{H}_{\mathrm{a}}$ diterima. Maka dapat disimpulkan bahwa ada pengaruh model Team Assisted Individualization terhadap hasil belajar biologi siswa kelas X di SMA Negeri 8 Lubuklinggau Tahun Pelajaran 2016/2017. Untuk penelitian selanjutnya sebaiknya tidak hanya mengukur hasil belajar ranah kognitif saja tetapi juga mengukur hasil belajar pada ranah afektif dan psikomotornya.

\section{REFERENSI}

Arikunto, S. (2010). Prosedur penelitian suatu pendekatan praktek. Jakarta: Rineka Cipta.

Erdriani, D. (2014). Pengaruh Model pembelajaran kooperatif tipe teams assisted individualization (TAI) terhadap hasil belajar matematika siswa kelas VII SMPN 5 Sungai Limau Kabupaten Padang Pariaman. Jurnal KomTekInfo Fakultas IImu Kedokteran Volume 1 Nomor 2 Desember 2014.

Halih, M. (2016). Pengaruh pembelajaran TAI (team assisted individualization) terhadap hasil belajar siswa. Jurnal Buana Matematika Volume 6 Nomor 2 Tahun 2016.

Isa, M., Kaldun, I., dan Halim, A. (2017). Penerapan model pembelajaran kooperatif tipe TAI untuk meningkatkan penguasaan konsep dan berpikir kritis siswa pada materi hidrokarbon. Jurnal IPA dan Pembelajaran IPA (JIPI), 1(2): 213-233, Desember 2017.

Mulyono, O., Bustami, Y., \& Julung, H. (2017). Peningkatan hasil belajar kognitif siswa biologi sekolah menengah pertama melalui metode demonstrasi. JPBIO (Jurnal Pendidikan Biologi), 2(2): 15-19.

Reflianto, A., Bustami, Y., \& Syafruddin, D. (2019). Efektivitas metode sosiodrama terhadap hasil belajar kognitif dan minat belajar siswa biologi. Assimilation: Indonesian Journal of Biology Education (AIJBE), 2(1): 1-6.

Sanjaya. (2006). Strategi pembelajaran berorientasi standar proses pendidikan. Jakarta: Kencana.

Slameto. (2010). Belajar dan faktor-faktor yang mempengaruhi. Jakarta: Rineka Cipta.

Tilyani. (2010). Penerapan model pembelajaran cooperative learning. Yogyakarta: Pustaka Pelajar.

Trianto. (2007). Model-model pembelajaran inovatif berorientasi konstruktivistik. Jakarta: Prestasi Pustaka. 